\title{
Karakter Tanaman Kelor (Moringa oleifera Lam.) Aksesi Kabupaten Lombok Utara
}

\section{Characteristics of North Lombok Moringa oleifera Lam. Accession}

\author{
Wahyu Risna Rianto ${ }^{1)}$, Sumarjan ${ }^{2}$, Bambang Budi Santoso*3) \\ ${ }^{1)}$ Program Studi Agroekoteknologi Fakultas Pertanian UNRAM \\ ${ }^{2)}$ Kelompok Peneliti Bidang Ilmu Pemuliaan Tanaman, Fakultas Pertanian UNRAM \\ ${ }^{3}$ Kelompok Peneliti Bidang Ilmu Pengembangan Lahan Kering, Fakultas Pertanian UNRAM \\ *corresponding author, email: bbsjatropha1963@gmail.com
}

Manuscript received: 14-05-2020. Accepted: 30-06-2020

\begin{abstract}
ABSTRAK
Penelitian bertujuan untuk mendeskripsikan karakter morfologi dan menentukan hubungan kekerabatan antar aksesi kelor (Moringa oleifera Lam.) yang tumbuh dan berkembang di Kabupaten Lombok Utara. Penelitian dilaksanakan pada Februari-Mei 2017, dengan menggunakan metode Deskriptif dan survei secara langsung serta pengamatan sampel secara sengaja (purposive sampling) dengan bantuan lembar observasi dan kuestioner yang terdiri atas 38 sampel aksesi. Data dianalisis menggunakan Analisis Hierarchical Cluster Dendogram program SPSS 16. Hasil penelitian menunjukkan bahwa hubungan kekerabatan terdekat yaitu antara aksesi Bayan-3 dan Bayan-4 dengan nilai koefisien sebesar 12,212 dan hubungan kekerabatan terjauh antara aksesi Pemenang-1 dan Gangga-2 dengan nilai koefisien sebesar 70,773. Dendogram menunjukkan bahwa dari 38 aksesi yang diamati, terbagi menjadi 8 kelompok, dan pada garis fenon distance 25 terjadi penggabungan antara aksesi Gangga-2 dengan kelompok aksesi lainnya. Di antara tanaman kelor aksesi Kabupaten Lombok Utara terdapat tingkat hubungan kekerabatan yang dekat.
\end{abstract}

Kata kunci: dendogram; kekerabatan; morfologi; survei

ABSTRACT
The research aims to describe the morphological character and determine the genetic relationship among
the Moringa oleifera Lam. accessions grown and develop in North Lombok Regency. The study was
conducted in February-May 2017, using descriptive methods and direct surveys and purposive sampling
with the observation sheets and questionnaires consisting of 38 accession samples. Data were analyzed
using Hierarchical Cluster Analysis SPSS 16 program. The results shows that the closest gentic
relationship was between Bayan-3 and Bayan- 4 accessions with a coefficient value of 12.21 and the
farthest between Pemenangr-1 and Gangga-2 accessions with coefficient values of 70.77 . Among of the
38 accessions observed, it was divided into 8 groups, and at the phenon distance line 25 there was a


merger between the Ganga- 2 accessions and other accession groups. There was a close level of geetic relationship among the moringa plant accessions in North Lombok Regency.

Keyword: dendogram; genetic relationship; morphology; survey

\section{PENDAHULUAN}

Moringa oleifera Lam. yang di Indonesia dikenal sebagai tanaman kelor merupakan tanaman yang diperkirakan berasal dari Agra dan Oudh yang terletak di Barat Laut India, wilayah pegunungan Himalaya bagian Selatan yang kemudian terdistribusikan ke Filipina, Kamboja, Amerika Tengah, Amerika Utara dan Selatan serta Kepulauan Karibia (Morton, 1991).

Tanaman kelor adalah tanaman berkayu lunak dan selama berabad-abad telah diadvokasi sebagai bahan pengobatan tradisional dan penggunaan industri lainnya. Semua bagian dari tanaman kelor dapat dimakan (dikonsumsi) manusia dan hewan, serta keperluan industri lainnya (Fuglie, 2001; Tsaknis et.al., 1999). Selain itu, tanaman ini telah ditemukan sebagai sumber bahan obat-obatan dan juga menunjukkan sifat antimikroba (Alessandro et al., 2015; Fahey, 2005), sehingga tanaman ini disebut sebagai pohon ajaib dan multiguna. Dalam beberapa waktu terakhir ini, tanaman kelor telah diadvokasi sebagai sumber yang luar biasa dari protein, mineral, dan vitamin yang sangat mudah dicerna untuk memerangi kasus kekurangan gizi di beberapa Negara (Fahey, 2005).

Seiring dengan semakin populernya pemanfaatan tanaman kelor, terutama daunnya, maka upaya pengembangan teknologi bercocok tanam dari tanaman ini secara intensif telah dan terus dikembangkan. Khususnya di Indonesia, pengembangan tanaman kelor pada aspek pemuliaan belum menghasilkan suatu jenis-jenis tertentu yang memilki keunggulan terutama berhabitus rendah (pendek) dan berkanopi lebat. Upaya untuk menghasilkan sifat-sifat agronomis yang dikehendaki dari tanaman kelor dapat dimulai dengan identifikasi beberapa aksesi atau populasi yang ada di daerah-daerah atau wilayah yang dijumpai banyak tumbuh dan berkembang tanaman ini. Salah satu wilayah yang dijumpai banyak tumbuh dan berkembang tanaman kelor adalah di kawasan Kabupaten Lombok Utara. Kawasan yang ditumbuhi oleh tanaman kelor di wilayah ini sangat luas dengan berbedaan yang cukup lebar pada factor curah hujan dan topografi serta tipe tanah, yang sudah pasti pula sebagai factor utama penyebab adanya keragaman genatik ataupun keragaman fenotip dari tanaman kelor ini.

Sehubungan dengan tanaman kelor menyerbuk silang dengan bantuan serangga sebagai pollinator (Orwa et al, 2009), maka sudah pasti turunan yang kemudian membentuk populasi memiliki tingkat keragaman yang tinggi. Identifikasi awal dari suatu populasi alam atau aksesi merupakan suatu kegiatan karakterisasi semua sifat yang dimiliki oleh sumber keragaman genetik tanaman atau aksesi tersebut. Identifikasi dilakukan untuk mencari dan mengenal ciriciri taksonomik individu yang beranekaragam dan memasukkannya ke dalam suatu takson (Mayr dan Ashlock 1999). Identifikasi berdasarkan karakter morfologi sangat berguna untuk mengetahui berbagai jenis dan keragaman tanaman kelor di Kabupaten Lombok Utara, dan kemudian dapat digunakan sebagai dasar pengembangannya untuk mendapatkan jenis-jenis unggul. 
Ketidaktersediaan informasi tentang keragaman tanaman kelor yang terdapat di Kabupaten Lombok Utara, maka artikel ini memaparkan hasil penelitian terkait karakter morfologi dan hubungan kekerabatan tanaman kelor yang tumbuh dan berkembang di Kabupaten Lombok Utara.

\section{BAHAN DAN METODE}

Penelitian telah dilaksanakan pada Februari-Agustus 2017, pada tanaman kelor yang tumbuh di lima Kecamatan yang ada di Kabupaten Lombok Utara yaitu Kecamatan Pemenang, Kecamatan Tanjung, Kecamatan Gangga, Kecamatan Kayangan, dan Kecamatan Bayan.

Metode yang digunakan adalah metode survei secara langsung dan pengambilan sampel secara sengaja (purposive sampling) dengan bantuan lembar observasi dan kuesioner. Pada setiap kecamatan diambil 10 persen tanaman sampel dari jumlah populasi tanaman kelor yang terdapat dan terhitung pada tiap-tiap kecamatan. Kriteria yang ditetapkan sebagai tanaman sampel memiliki ciri-ciri umur tanaman 5 tahun atau lebih dan pohon dewasa yang pernah berbuah.

Penelitian diawali dengan survei-observasi lokasi untuk melihat kondisi daerah yang akan dipilih sebagai lokasi penelitian dan sekaligus keberadaan populasi tanaman. Informasi lainnya berupa data curah hujan di setiap kecamatan yang diperoleh pada dinas terkait. Selanjutnya, masing-masing kecamatan ditetapkan jumlah tanaman sampel yang dipilih sebagai objek penelitian, yaitu Kecamatan Pemenang sebanyak 8 sampel, di Kecamatan Gangga, Kecamatan Kayangan, dan di Kecamatan Bayan masing-masing sebanyak 10 sampel.

Variabel yang diamati meliputi bentuk batang, arsitektur pohon, bentuk daun, bentuk bunga, bentuk buah, bentuk biji, data ekobiologi tanaman, serta wawancara dengan warga sekitar terkait dengan teknik penanaman dan pemanfaatan tanaman. Data dianalisa secara deskriptif. Kemudian untuk mengetahui tingkat hubungan kekerabatan dilakukan dengan menggunakan Analisis Dendogram menggunakan Analysis Hierarchical Cluster dari program SPSS 16.

\section{Gambaran Umum Lokasi Penelitian}

\section{HASIL DAN PEMBAHASAN}

Kabupaten Lombok Utara terletak antara $08^{0} 21^{\prime}$ LS dan $116^{\circ} 05^{\prime}$ BT dengan luas wilayah 809,53 terbagi di kecamatan Pemenang 81,09 hektar; kecamatan Tanjung 115,64 hektar , kecamatan Gangga 157,35 hektar, kecamatan Kayangan 126,35 hektar, dan kecamatan Bayan 329,1 hektar (BPS, 2016).

Pada masing-masing kecamatan, letak topografinya cenderung datar, rata dan membentang luas, namun ada kecamatan yang topografinya agak berbukit yaitu Kecamatan Kayangan dan Kecamatan Gangga. Tingkat curah hujan di Lombok Utara berkisar antara 3$539 \mathrm{~mm} /$ bulan. Ketinggian tempat pengambilan sampel berkisar antara 18-317 m dpl. Ketinggian tempat terendah berada di Kecamatan Pemenang tepatnya di Desa Malaka dan ketinggian tempat tertinggi berada di Desa Genggelang Kecamatan Gangga. 


\section{Karakteristik Tanaman Kelor}

Tabel 1. Keragaan batang tanaman kelor di Kabupaten Lombok Utara

\begin{tabular}{|c|c|c|c|c|c|c|c|}
\hline \multirow{2}{*}{$\begin{array}{c}\text { Tanaman } \\
\text { Sampel }\end{array}$} & \multicolumn{7}{|c|}{ Variabel Batang } \\
\hline & $\begin{array}{l}\text { TT } \\
(\mathbf{m})\end{array}$ & $\begin{array}{l}\text { LB } \\
(\mathbf{c m})\end{array}$ & WB & $\mathbf{G}$ & PK & KKB & $\mathbf{A P}$ \\
\hline $\mathrm{P} 1$ & 8 & 57 & Putih Keabuan & Merah & Licin & $0.4 \mathrm{~cm}$ & Miring \\
\hline $\mathrm{P} 2$ & 13 & 122 & Putih Keabuan & Cokelat & Retak-retak & $0.5 \mathrm{~cm}$ & Miring \\
\hline P3 & 11.40 & 77 & Putih Keabuan & Cokelat & Retak-retak & $0.6 \mathrm{~cm}$ & Condong \\
\hline P4 & 14.06 & 142 & Putih Keabuan & Cokelat & Retak-retak & $0.7 \mathrm{~cm}$ & Condong \\
\hline P5 & 11.18 & 99 & Putih kecokelatan & Merah & Retak-retak & $0.6 \mathrm{~cm}$ & Lurus \\
\hline P6 & 15.90 & 68 & Putih & Merah & Retak-retak & $0.6 \mathrm{~cm}$ & Lurus \\
\hline P7 & 11.25 & 125 & Cokelat & Cokelat & Retak-retak & $0.6 \mathrm{~cm}$ & Miring \\
\hline P8 & 10.62 & 89 & Putih & Merah & Licin & $0.5 \mathrm{~cm}$ & Miring \\
\hline G1 & 12.18 & 66 & Cokelat kehitaman & Hitam & Retak-retak & $0.9 \mathrm{~cm}$ & Condong \\
\hline $\mathrm{G} 2$ & 9.31 & 64 & Cokelat kehitaman & Hitam & Licin. Retak-retak & $0.9 \mathrm{~cm}$ & Lurus \\
\hline G3 & 11.12 & 86 & Hitam & Hitam & Retak-retak & $0.9 \mathrm{~cm}$ & Miring \\
\hline G4 & 11.22 & 120 & Putih & Merah & Retak-retak & $0.9 \mathrm{~cm}$ & Lurus \\
\hline G5 & 11.93 & 115 & Hitam & Hitam & Retak-retak & $0.9 \mathrm{~cm}$ & Lurus \\
\hline G6 & 9.70 & 62 & Cokelat muda & Hitam & Retak-retak & $0.4 \mathrm{~cm}$ & Miring \\
\hline G7 & 16.32 & 70 & Hitam kehijauan & Hitam & Retak-retak & $0.6 \mathrm{~cm}$ & Condong \\
\hline G8 & 14.56 & 170 & Hitam kehijauan & Merah & $\begin{array}{l}\text { Licin dan Retak- } \\
\text { retak }\end{array}$ & $0.6 \mathrm{~cm}$ & Condong \\
\hline G9 & 11.68 & 83 & Putih kecokelatan & Merah & Licin. Retak-retak & $0.6 \mathrm{~cm}$ & Lurus \\
\hline G10 & 9.78 & 76 & Putih kecokelatan & Merah & Licin & $0.6 \mathrm{~cm}$ & Lurus \\
\hline $\mathrm{K} 1$ & 13.23 & 111 & Cokelat kehitaman & Hitam & Licin. Retak-retak & $0.5 \mathrm{~cm}$ & Condong \\
\hline $\mathrm{K} 2$ & 8.73 & 73 & Putih & Merah & Licin & $0.4 \mathrm{~cm}$ & Lurus \\
\hline $\mathrm{K} 3$ & 10.21 & 64 & Putih kehijauan & Hitam & Licin & $0.4 \mathrm{~cm}$ & Lurus \\
\hline K4 & 12.94 & 94 & Cokelat kehitaman & Hitam & Retak-retak & $0.4 \mathrm{~cm}$ & Condong \\
\hline K5 & 10.28 & 67 & Putih kehijauan & Merah & Retak-retak & $0.5 \mathrm{~cm}$ & Lurus \\
\hline K6 & 14.28 & 79 & Hitam kehijauan & Hitam & Retak-retak & $0.6 \mathrm{~cm}$ & Condong \\
\hline $\mathrm{K} 7$ & 9.87 & 67 & Cokelat & Merah & Licin & $0.5 \mathrm{~cm}$ & Condong \\
\hline K8 & 10.12 & 65 & Putih kehijauan & Merah & Licin & $0.6 \mathrm{~cm}$ & Lurus \\
\hline K9 & 13.78 & 84 & Putih kecokelatan & Hitam & Licin. Retak-retak & $0.6 \mathrm{~cm}$ & Lurus \\
\hline K10 & 10.56 & 80 & Putih kehijauan & Merah & Licin & $0.6 \mathrm{~cm}$ & Lurus \\
\hline B1 & 7.06 & 52 & Putih & Hitam & Licin & $0.4 \mathrm{~cm}$ & Condong \\
\hline B2 & 7.17 & 72 & Putih & Hitam & Licin & $0.4 \mathrm{~cm}$ & Lurus \\
\hline B3 & 9.43 & 69 & Cokelat tua & Merah & Retak-retak & $0.9 \mathrm{~cm}$ & Lurus \\
\hline B4 & 10.13 & 104 & Cokelat tua & Merah & Retak-retak & $0.9 \mathrm{~cm}$ & Lurus \\
\hline B5 & 7.10 & 60 & Hitam & Hitam & Licin & $0.6 \mathrm{~cm}$ & Lurus \\
\hline B6 & 7.94 & 65 & Hitam & Hitam & Licin & $0.6 \mathrm{~cm}$ & Lurus \\
\hline B7 & 10.66 & 75 & Cokelat kehitaman & Hitam & Licin & $0.6 \mathrm{~cm}$ & Lurus \\
\hline B8 & 15.42 & 90 & Cokelat kehitaman & Merah & Retak-retak & $0.6 \mathrm{~cm}$ & Miring \\
\hline B9 & 12.48 & 70 & Putih & Merah & Retak-retak & $0.6 \mathrm{~cm}$ & Lurus \\
\hline B10 & 12.82 & 90 & Putih kecokelatan & Merah & Licin & $0.6 \mathrm{~cm}$ & Lurus \\
\hline
\end{tabular}

Keterangan: P1 (Nama Kecamatan dan nomor urut sampel), TT (Tinggi Tanaman), LB (Lingkar Batang), WB (Warna Batang), PF (Penampilan Fisik), G (Getah), PK (Penampilan Kulit), KKB (Ketebalan Kulit Batang), AP (Arah Pertumbuhan).

Pada Tabel 1 menguraikan karakter batang tanaman kelor yang tumbuh dan berkembang di Kabupaten Lombok Utara. Percabangan pohon kelor yang tumbuh di Lombok Utara bertipe simpodial. Percabangan simpodial merupakan tipe percabangan yang dicirikan batang pokok atau utama sulit ditentukan, karena pada perkembangan selanjutnya batang pokok menghentikan pertumbuhannya atau mungkin kalah besar dan kalah cepat 
pertumbuhannya dibandingkan cabangnya. Tipe kanopi tanaman kelor yang tumbuh di Kabupaten Lombok Utara berbentuk seperti payung. Ini sesuai dengan yang dikatakan Orwa et al. (2009) bahwa tanaman kelor berbentuk seperti payung.

Rata-rata tinggi tanaman kelor di Kecamatan Pemenang adalah 11,93 m, di Kecamatan Gangga memiliki rata-rata tinggi 11,78 m, di Kecamatan Kayangan memiliki rata-rata tinggi 11,40 m, dan di Kecamatan Bayan memiliki rata-rata tinggi 10,02 m. Berdasarkan tinggi tersebut, sesuai dengan pendapat Krisnadi (2015), bahwa ketinggian tanaman kelor mencapai 7-12 m. Sementara Kelor di Zaire, tanaman dapat mencapai ketinggian $4 \mathrm{~m}$ dalam setahun dan dapat meningkat lagi hingga 6-15 m (Price, 1985).

Ukuran lingkar batang tanaman kelor di Kecamatan Pemenang rata-rata sebesar 97,4 m, di Kecamatan Gangga 91,2 cm, di Kecamatan Kayangan 78,4 cm, dan di Kecamatan Bayan sebesar 74,7 cm. Lingkar batang yang bervariasi ini diduga dipengaruhi oleh umur tanaman yang bervariasi pula. Hasil wawancara bahwa umur tanaman yang diamati berkisar $5->10$ tahun. Namun demikian, besar-kecilnya lingkar batang dari suatu tanaman juga sangat dipengaruhi oleh kondisi lingkungan terutama tingkat kesuburan tanah.

Batang tanaman kelor berwarna putih keabuan, cokelat hingga hitam. Kulit tanaman kelor memiliki getah yang berwarna didominasi oleh warna merah dan cokelat kehitaman. Hal ini sesuai dengan pendapat Roloff et al. (2009), menyatakan bahwa kulit kelor memiliki warna putih keabuan dan ketika terluka kulit memancarkan getah yang berwarna cokelat kemerahan atau hitam. Kelor di Lombok Utara memiliki penampakan fisik yang keras dan kuat. Kulit pohon kelor memiliki penampilan yang retak-retak dan licin. Kelor memiliki kulit yang pecahpecah dan berkutil atau gabus dan kemudian menjadi kasar (Roloff et al, 2009).

Daun tanaman kelor di Lombok Utara memiliki warna hijau muda dan hijau tua. Hal ini sesuai dengan yang dilaporkan oleh Orwa et al. (2009) bahwa helai daun muda berwarna hijau muda dan untuk helai daun dewasa berwarna hijau tua. Pada sisi tipe, daun kelor di Lombok Utara memiliki tipe kemajemukan daun menyirip tingkat tiga dengan bentuk anak daun didominasi oleh bentuk bulat telur, Susunan tulang daun menyirip, memiliki tepi daun yang rata, serta keadaan pangkal tangkai daun yang membengkak. Untuk alat tambahan pada daun seperti daun penumpu (stipula), selaput bumbung (ochrea) dan lidah daun (ligula) tidak ditemukan pada daun kelor.

Daun kelor umumnya tripinnate, memiliki panjang hingga $45 \mathrm{~cm}$, tangkai berbentuk bulat panjang, tangkai daun memiliki bulu-bulu halus (Roloff et al, 2009). Sifat daun umumnya tipis dan lunak. Biasanya daun muda memiliki tekstur daun yang lembut dan lemas, sedangkan daun yang tua memiliki tekstur yang agak kaku dan keras (Aminah et al, 2015). Pohon kelor setelah delapan bulan sudah mulai berbunga terus-menerus sepanjang tahun. Bunga kelor berbentuk malai dan memiliki aroma yang harum. Bunga kelor muncul di ketiak daun (axillaris). Warna bunga kelor di Lombok Utara umumnya berwarna putih kekuningan. Hal ini sesuai dengan pendapat yang di kemukakan oleh Krisnadi (2015) dan Roloff et al. (2009), bahwa bunga kelor memiliki warna putih kekuningan dan terletak di bagian ketiak daun. 
Tabel 2. Keragaan daun tanaman kelor di Kabupaten Lombok Utara

\begin{tabular}{|c|c|c|c|c|c|c|}
\hline \multirow[b]{2}{*}{$\begin{array}{c}\text { Tanaman } \\
\text { Sampel }\end{array}$} & \multicolumn{6}{|c|}{ Variabel Daun } \\
\hline & WD & $\begin{array}{c}\text { UD } \\
\text { panjang } x \\
\text { lebar } \\
(\mathrm{cm})\end{array}$ & BAD & SD & STD & TKD-B \\
\hline P1 & Hijau Tua & $39.4 \times 30.7$ & Lonjong & Tipis Lunak & Menyirip & Gasal Rangkap Tiga Berbulu \\
\hline $\mathrm{P} 2$ & Hijau Muda & $36.8 \times 30.4$ & Bulat Telur & Tipis Agak Lunak & Menyirip & Gasal Rangkap Tiga Berbulu \\
\hline P3 & Hijau Muda & $39.6 \times 28.5$ & Lonjong & Tipis Lunak & Menyirip & Gasal Rangkap Tiga Berbulu \\
\hline $\mathrm{P} 4$ & Hijau Tua & $35.7 \times 26.4$ & Bulat Telur & Tebal Agak Lunak & Menyirip & Gasal Rangkap Tiga Berbulu \\
\hline P5 & Hijau Muda & $43.7 \times 26.7$ & Bulat Telur & Tipis Lunak & Menyirip & Gasal Rangkap Tiga Berbulu \\
\hline P6 & Hijau Tua & $39.2 \times 26.9$ & Bulat Telur & Tebal Agak Lunak & Menyirip & Gasal Rangkap Tiga Berbulu \\
\hline P7 & Hijau Tua & $43.2 \times 24.6$ & Bulat Telur & Tebal Agak Lunak & Menyirip & Gasal Rangkap Tiga Berbulu \\
\hline P8 & Hijau Muda & $32.2 \times 26.1$ & Bulat Telur & Tipis Lunak & Menyirip & Gasal Rangkap Tiga Berbulu \\
\hline G1 & Hijau Tua & $47 \times 39.7$ & Bulat Telur & Tipis Lunak & Menyirip & Gasal Rangkap Tiga Berbulu \\
\hline $\mathrm{G} 2$ & Hijau Tua & $41.5 \times 30.4$ & Bulat Telur & Tipis Lunak & Menyirip & Gasal Rangkap Tiga Berbulu \\
\hline G3 & Hijau Tua & $34.8 \times 26.8$ & Bulat Telur & Tebal Agak Lunak & Menyirip & Gasal Rangkap Tiga Berbulu \\
\hline G4 & Hijau Tua & $37.5 \times 23.5$ & Bulat Telur & Tebal Agak Lunak & Menyirip & Gasal Rangkap Tiga Berbulu \\
\hline G5 & Hijau Tua & $46.5 \times 27.8$ & Lonjong & Tipis Agak Lunak & Menyirip & Gasal Rangkap Tiga Berbulu \\
\hline G6 & Hijau Tua & $34.3 \times 25.3$ & Bulat Telur & Tipis Agak Lunak & Menyirip & Gasal Rangkap Tiga Berbulu \\
\hline G7 & Hijau Muda & $44.4 \times 32.8$ & Bulat Telur & Tipis Agak Lunak & Menyirip & Gasal Rangkap Tiga Berbulu \\
\hline G8 & Hijau Tua & $33.9 \times 25.6$ & Lonjong & Tipis Lunak & Menyirip & Gasal Rangkap Tiga Berbulu \\
\hline G9 & Hijau Tua & $33.9 \times 25.6$ & Lonjong & Tipis Lunak & Menyirip & Gasal Rangkap Tiga Berbulu \\
\hline G10 & Hijau Tua & $34.7 \times 28.3$ & Bulat Telur & Tipis Lunak & Menyirip & Gasal Rangkap Tiga Berbulu \\
\hline $\mathrm{K} 1$ & Hijau Muda & $46.1 \times 34.1$ & Bulat Telur & Tebal Agak Lunak & Menyirip & Gasal Rangkap Tiga Berbulu \\
\hline $\mathrm{K} 2$ & Hijau Tua & $56.8 \times 49.9$ & Bulat Telur & Tipis Agak Lunak & Menyirip & Gasal Rangkap Tiga Berbulu \\
\hline K3 & Hijau Tua & $44.4 \times 37.6$ & Bulat Telur & Tipis Agak Lunak & Menyirip & Gasal Rangkap Tiga Berbulu \\
\hline K4 & Hijau Muda & $39.6 \times 34.7$ & Bulat Telur & Tipis Agak Lunak & Menyirip & Gasal Rangkap Tiga Berbulu \\
\hline K5 & Hijau Tua & $38.4 \times 21.5$ & Bulat Telur & Tipis Lunak & Menyirip & Gasal Rangkap Tiga Berbulu \\
\hline K6 & Hijau Muda & $38.9 \times 35.3$ & Lonjong & Tipis Lunak & Menyirip & Gasal Rangkap Tiga Berbulu \\
\hline K7 & Hijau Tua & $46.9 \times 40.3$ & Bulat Telur & Tipis Lunak & Menyirip & Gasal Rangkap Tiga Berbulu \\
\hline K8 & Hijau Tua & $36.3 \times 30.7$ & Lonjong & Tipis Agak Lunak & Menyirip & Gasal Rangkap Tiga Berbulu \\
\hline K9 & Hijau Tua & $45.7 \times 33.2$ & Lonjong & Tipis Lunak & Menyirip & Gasal Rangkap Tiga Berbulu \\
\hline K10 & Hijau Muda & $40 \times 25.2$ & Bulat Telur & Tebal Agak Lunak & Menyirip & Gasal Rangkap Tiga Berbulu \\
\hline B1 & Hijau Muda & $40 \times 32.3$ & Lonjong & Tebal Agak Lunak & Menyirip & Gasal Rangkap Tiga Berbulu \\
\hline B2 & Hijau Muda & $37.3 \times 22.7$ & Lonjong & Tebal Agak Lunak & Menyirip & Gasal Rangkap Tiga Berbulu \\
\hline B3 & Hijau Muda & $49.3 \times 45$ & Bulat Telur & Tipis Lunak & Menyirip & Gasal Rangkap Tiga Berbulu \\
\hline B4 & Hijau Muda & $39 \times 29.3$ & Bulat Telur & Tipis Lunak & Menyirip & Gasal Rangkap Tiga Berbulu \\
\hline B5 & Hijau Muda & $46.7 \times 33.7$ & Bulat Telur & Tipis Lunak & Menyirip & Gasal Rangkap Tiga Berbulu \\
\hline B6 & Hijau Tua & $43.7 \times 28.7$ & Bulat Telur & Tebal Agak Lunak & Menyirip & Gasal Rangkap Tiga Berbulu \\
\hline B7 & Hijau Muda & $39 \times 25.2$ & Lonjong & Tipis Lunak & Menyirip & Gasal Rangkap Tiga Berbulu \\
\hline B8 & Hijau Tua & $34,5 \times 26,8$ & Bulat Telur & Tipis Lunak & Menyirip & Gasal Rangkap Tiga Berbulu \\
\hline B9 & Hijau Tua & $32,8 \times 23,7$ & Bulat Telur & Tebal Agak Lunak & Menyirip & Gasal Rangkap Tiga Berbulu \\
\hline B10 & Hijau Tua & $27,7 \times 17,7$ & Bulat Telur & Tipis Lunak & Menyirip & Gasal Rangkap Tiga Berbulu \\
\hline
\end{tabular}

Keterangan: WD (Warna Daun), UD (Ukuran Daun), BAD (Bentuk Anak Daun), SD (Sifat Daun), STD

(Susunan Tulang Daun), KFD (Keadaan Fulvinus Daun), TKD-B (Tipe Kemajemukan Daun-Bulu).

Tabel 3 menjelaskan fenologi pembungaan tanaman kelor aksesi Lombok Utara. Tanaman kelor umumnya berkelamin biseksual, yaitu bunga yang memiliki putik dan benang sari atau sering disebut dengan bunga sempurna atau hermaphrodit. Bunga kelor memiliki 5 kelopak yang mengelilingi 5 benang sari yang berwarna kuning kecokelatan dan 5 staminodia serta 1 putik. Bunga kelor yang biseksual ini memungkinkan untuk melakukan penyerbukan silang.

Ukuran malai per tandan bunga kelor di Kecamatan Pemenang memiliki panjang 17,6 $\mathrm{cm}$ dengan lebar 7,5 $\mathrm{cm}$ dan total bunga per tandan sebanyak 12 bunga. Kecamatan Gangga memiliki panjang bunga 18,93 $\mathrm{cm}$ dengan lebar 9,2 cm dan total bunga per tandan sebanyak 6 bunga. Di Kecamatan Kayangan memiliki panjang bunga $15 \mathrm{~cm}$ dengan lebar 7,4 cm dan total 
bunga per tandan sebanyak 7 bunga. Untuk kelor di Kecamatan Bayan memiliki panjang bunga $17,8 \mathrm{~cm}$ dengan lebar $8,2 \mathrm{~cm}$ dan total bunga per tandan sebanyak 8 bunga.

Tabel 3. Keragaan bunga tanaman kelor di Kabupaten Lombok Utara

\begin{tabular}{|c|c|c|c|c|c|}
\hline \multirow{3}{*}{$\begin{array}{c}\text { Tanaman } \\
\text { Sampel }\end{array}$} & \multicolumn{5}{|c|}{ Variabel Bunga } \\
\hline & \multirow[b]{2}{*}{ WB } & \multicolumn{2}{|c|}{ UB } & \multirow[b]{2}{*}{$\mathbf{K B}$} & \multirow[b]{2}{*}{ TB } \\
\hline & & $\begin{array}{c}\text { panjang } \\
(\mathrm{cm})\end{array}$ & $\begin{array}{c}\text { lebar } \\
(\mathrm{cm})\end{array}$ & & \\
\hline $\mathrm{P} 1$ & Putih kekuningan & 12.3 & 6.4 & Bunga sempurna & 7 \\
\hline $\mathrm{P} 2$ & Putih kekuningan & 14.3 & 5.6 & Bunga sempurna & 8 \\
\hline P3 & Putih kekuningan & 13.7 & 7.7 & Bunga sempurna & 7 \\
\hline $\mathrm{P} 4$ & Putih kekuningan & 19.2 & 6.2 & Bunga sempurna & 11 \\
\hline P5 & Putih kekuningan & 19.2 & 7.1 & Bunga sempurna & 15 \\
\hline P6 & Putih & 19.8 & 8.5 & Bunga sempurna & 16 \\
\hline P7 & Putih kekuningan & 23.2 & 10.4 & Bunga sempurna & 14 \\
\hline P8 & Putih & 18.9 & 8 & Bunga sempurna & 16 \\
\hline G1 & Putih & 17.3 & 7.3 & Bunga sempurna & 5 \\
\hline $\mathrm{G} 2$ & Putih & 17.9 & 7.1 & Bunga sempurna & 6 \\
\hline G3 & Putih & 22.6 & 8.5 & Bunga sempurna & 9 \\
\hline G4 & Putih & 20.7 & 8.2 & Bunga sempurna & 9 \\
\hline G5 & Putih & 26 & 10.7 & Bunga sempurna & 5 \\
\hline G6 & Putih kekuningan & 13.9 & 7.2 & Bunga sempurna & 5 \\
\hline G7 & Putih & 15.5 & 8 & Bunga sempurna & 6 \\
\hline G8 & Putih & 12.4 & 5.4 & Bunga sempurna & 3 \\
\hline G9 & Putih & 23.6 & 4.2 & Bunga sempurna & 5 \\
\hline G10 & Putih kekuningan & 19.4 & 5.3 & Bunga sempurna & 7 \\
\hline $\mathrm{K} 1$ & Putih kekuningan & 11.3 & 7.7 & Bunga sempurna & 11 \\
\hline $\mathrm{K} 2$ & Putih kekuningan & 14.3 & 6.9 & Bunga sempurna & 4 \\
\hline $\mathrm{K} 3$ & Putih kekuningan & 13.9 & 6.9 & Bunga sempurna & 5 \\
\hline K4 & Putih kekuningan & 15.5 & 7.1 & Bunga sempurna & 7 \\
\hline K5 & Putih kekuningan & 15.6 & 7.1 & Bunga sempurna & 6 \\
\hline K6 & Putih kekuningan & 14.8 & 6.8 & Bunga sempurna & 9 \\
\hline $\mathrm{K} 7$ & Putih kekuningan & 17.1 & 7.8 & Bunga sempurna & 7 \\
\hline K8 & Putih & 14.7 & 8 & Bunga sempurna & 5 \\
\hline K9 & Putih & 16.2 & 9.2 & Bunga sempurna & 9 \\
\hline K10 & Putih kekuningan & 16.2 & 6.4 & Bunga sempurna & 7 \\
\hline B1 & Putih kekuningan & 16.2 & 6.7 & Bunga sempurna & 11 \\
\hline B2 & Putih kekuningan & 17.1 & 9 & Bunga sempurna & 10 \\
\hline B3 & Putih & 20.5 & 9.8 & Bunga sempurna & 7 \\
\hline B4 & Putih & 18.8 & 7.8 & Bunga sempurna & 9 \\
\hline B5 & Putih & 18.2 & 6.4 & Bunga sempurna & 7 \\
\hline B6 & Putih & 18.9 & 8 & Bunga sempurna & 5 \\
\hline B7 & Putih kekuningan & 15.3 & 12 & Bunga sempurna & 8 \\
\hline B8 & Putih kekuningan & 18.5 & 7.6 & Bunga sempurna & 7 \\
\hline B9 & Putih & 17.4 & 7.2 & Bunga sempurna & 6 \\
\hline B10 & Putih kekuningan & 17.4 & 7.4 & Bunga sempurna & 9 \\
\hline
\end{tabular}

Keterangan: $\quad$ P1 (Nama Kecamatan dan nomor urut sampel), WB (Warna Bunga), UB (Ukuran Bunga), KB (Kelamin Bunga), TB (Total Bunga per Tandan)

Buah kelor berbentuk segitiga memanjang yang mendekati ke bentuk lonjong dengan sifat pinggang yang bergelombang dan ujung buah berbentuk meruncing serta buah memiliki garis-garis di sisi buah. Ketika buah masak, buah akan memecah menjadi 3 bagian (karpel). Ketika muda, buah kelor berwarna hijau dan ketika buah tua buah kelor akan berwarna cokelat 
(Tabel 4). Hal ini sesuai dengan pendapat yang dikemukakan oleh Orwa et al. (2009), bahwa buah kelor secara bertahap akan berbentuk lonjong dengan ujung buah yang meruncing, dengan dua lekukan pada buah, biasanya memecah menjadi 3 bagian.

Tabel 4. Keragaan buah tanaman kelor di Kabupaten Lombok Utara

\begin{tabular}{|c|c|c|c|c|c|c|c|c|}
\hline \multirow{3}{*}{$\begin{array}{c}\text { Tanaman } \\
\text { Sampel }\end{array}$} & \multicolumn{8}{|c|}{ Variabel Buah } \\
\hline & \multirow[b]{2}{*}{ WB } & \multicolumn{2}{|c|}{ UB } & \multirow[b]{2}{*}{ BB } & \multirow[b]{2}{*}{ SP } & \multirow[b]{2}{*}{ WDB } & \multirow[b]{2}{*}{ BUB } & \multirow{2}{*}{$\begin{array}{c}\text { Ada/ } \\
\text { Tidak } \\
\text { Garis }\end{array}$} \\
\hline & & $\begin{array}{c}\mathbf{p} \\
(\mathbf{c m})\end{array}$ & I (cm) & & & & & \\
\hline P1 & Cokelat Muda & 42 & 2.5 & $\begin{array}{l}\text { Segitiga } \\
\text { Memanjang }\end{array}$ & Bergelombang & $\begin{array}{l}\text { Putih } \\
\text { kecokelatan }\end{array}$ & Meruncing & Bergaris \\
\hline P2 & Cokelat Tua & 40.5 & 0.8 & $\begin{array}{l}\text { Segitiga } \\
\text { Memanjang }\end{array}$ & Bergelombang & $\begin{array}{l}\text { Putih } \\
\text { kecokelatan }\end{array}$ & Meruncing & Bergaris \\
\hline P3 & Cokelat Muda & 34 & 1.8 & $\begin{array}{l}\text { Segitiga } \\
\text { Memanjang }\end{array}$ & Bergelombang & Cokelat & Meruncing & Bergaris \\
\hline P4 & Cokelat Muda & 30.7 & 1.9 & $\begin{array}{l}\text { Segitiga } \\
\text { Memanjang }\end{array}$ & Bergelombang & $\begin{array}{l}\text { Putih } \\
\text { kecokelatan }\end{array}$ & Meruncing & Bergaris \\
\hline P5 & Cokelat Tua & 42.5 & 1.6 & $\begin{array}{l}\text { Segitiga } \\
\text { Memanjang }\end{array}$ & Bergelombang & Cokelat & Meruncing & Bergaris \\
\hline P6 & Cokelat Muda & 34.8 & 1.7 & $\begin{array}{l}\text { Segitiga } \\
\text { Memanjang }\end{array}$ & Bergelombang & $\begin{array}{l}\text { Putih } \\
\text { kecokelatan }\end{array}$ & Runcing & Bergaris \\
\hline P7 & Cokelat Tua & 40 & 1.6 & $\begin{array}{l}\text { Segitiga } \\
\text { Memanjang }\end{array}$ & Bergelombang & Cokelat & Meruncing & Bergaris \\
\hline P8 & Cokelat Muda & 40.9 & 2.1 & $\begin{array}{l}\text { Segitiga } \\
\text { Memanjang }\end{array}$ & Bergelombang & Cokelat & Runcing & Bergaris \\
\hline G1 & Cokelat Muda & 31.7 & 1.5 & $\begin{array}{l}\text { Segitiga } \\
\text { Memanjang }\end{array}$ & Bergelombang & $\begin{array}{l}\text { Putih } \\
\text { kecokelatan }\end{array}$ & Runcing & Bergaris \\
\hline G2 & Cokelat Tua & 42.3 & 1.8 & $\begin{array}{l}\text { Segitiga } \\
\text { Memanjang }\end{array}$ & Bergelombang & Cokelat Tua & Runcing & Bergaris \\
\hline G3 & Cokelat Muda & 35.5 & 2.4 & $\begin{array}{l}\text { Segitiga } \\
\text { Memanjang }\end{array}$ & Bergelombang & $\begin{array}{l}\text { Putih } \\
\text { kecokelatan }\end{array}$ & Runcing & Bergaris \\
\hline G4 & Cokelat Muda & 36.2 & 2.4 & $\begin{array}{l}\text { Segitiga } \\
\text { Memanjang }\end{array}$ & Bergelombang & $\begin{array}{l}\text { Putih } \\
\text { kecokelatan }\end{array}$ & Meruncing & Bergaris \\
\hline G5 & Cokelat Tua & 28.8 & 1.9 & $\begin{array}{l}\text { Segitiga } \\
\text { Memanjang }\end{array}$ & Bergelombang & Cokelat Tua & Meruncing & Bergaris \\
\hline G6 & Cokelat Muda & 42.1 & 2.1 & $\begin{array}{l}\text { Segitiga } \\
\text { Memanjang }\end{array}$ & Bergelombang & $\begin{array}{l}\text { Putih } \\
\text { kecokelatan }\end{array}$ & Meruncing & Bergaris \\
\hline G7 & Cokelat Tua & 43.4 & 2.3 & $\begin{array}{l}\text { Segitiga } \\
\text { Memanjang }\end{array}$ & Bergelombang & Cokelat Tua & Meruncing & Bergaris \\
\hline G8 & Cokelat Tua & 30.1 & 2.1 & $\begin{array}{l}\text { Segitiga } \\
\text { Memanjang }\end{array}$ & Bergelombang & Cokelat Tua & Meruncing & Bergaris \\
\hline G9 & Cokelat Muda & 31.6 & 2.1 & $\begin{array}{l}\text { Segitiga } \\
\text { Memanjang }\end{array}$ & Bergelombang & $\begin{array}{l}\text { Putih } \\
\text { kecokelatan }\end{array}$ & Meruncing & Bergaris \\
\hline G10 & Cokelat Muda & 32.8 & 2.1 & $\begin{array}{l}\text { Segitiga } \\
\text { Memanjang }\end{array}$ & Bergelombang & Cokelat Tua & Meruncing & Bergaris \\
\hline K1 & Cokelat Muda & 34.8 & 2 & $\begin{array}{l}\text { Segitiga } \\
\text { Memanjang }\end{array}$ & Bergelombang & Cokelat Tua & Meruncing & Bergaris \\
\hline K2 & Cokelat Tua & 43.7 & 2 & $\begin{array}{l}\text { Segitiga } \\
\text { Memanjang }\end{array}$ & Bergelombang & Cokelat Tua & Meruncing & Bergaris \\
\hline
\end{tabular}

Keterangan: $\quad$ Biji dari semua sampel berkarpel (sayap) di tiga punggung biji. WB (Warna Buah), UB (Ukuran Buah), BB (Bentuk Buah), SP (Sifat Pinggang), K (Karpel), WDB (Warna Daging Buah), BUB (Bentuk Ujung Buah). 
Tabel 4. Keragaan buah tanaman kelor di Kabupaten Lombok Utara (lanjutan)

\begin{tabular}{|c|c|c|c|c|c|c|c|c|}
\hline \multirow{3}{*}{$\begin{array}{c}\text { Tanaman } \\
\text { Sampel }\end{array}$} & \multicolumn{8}{|c|}{ Variabel Buah } \\
\hline & \multirow[b]{2}{*}{ WB } & \multicolumn{2}{|c|}{ UB } & \multirow[b]{2}{*}{ BB } & \multirow[b]{2}{*}{ SP } & \multirow[b]{2}{*}{ WDB } & \multirow[b]{2}{*}{ BUB } & \multirow{2}{*}{$\begin{array}{c}\text { Ada/ } \\
\text { Tidak } \\
\text { Garis }\end{array}$} \\
\hline & & $\underset{(\mathbf{c m})}{\mathbf{p}}$ & I (cm) & & & & & \\
\hline K3 & Cokelat Muda & 42.6 & 1.9 & $\begin{array}{l}\text { Segitiga } \\
\text { Memanjang }\end{array}$ & Bergelombang & $\begin{array}{l}\text { Putih } \\
\text { kecokelatan }\end{array}$ & Meruncing & Bergaris \\
\hline K4 & Cokelat Muda & 43.4 & 2 & $\begin{array}{l}\text { Segitiga } \\
\text { Memanjang }\end{array}$ & Bergelombang & $\begin{array}{l}\text { Putih } \\
\text { kecokelatan }\end{array}$ & Meruncing & Bergaris \\
\hline K5 & Cokelat Muda & 41 & 1.9 & $\begin{array}{l}\text { Segitiga } \\
\text { Memanjang }\end{array}$ & Bergelombang & $\begin{array}{l}\text { Putih } \\
\text { kecokelatan }\end{array}$ & Meruncing & Bergaris \\
\hline K6 & Cokelat Tua & 38.7 & 2 & $\begin{array}{l}\text { Segitiga } \\
\text { Memanjang }\end{array}$ & Bergelombang & $\begin{array}{l}\text { Putih } \\
\text { kecokelatan }\end{array}$ & Meruncing & Bergaris \\
\hline K7 & Cokelat Tua & 32.4 & 1.9 & $\begin{array}{l}\text { Segitiga } \\
\text { Memanjang }\end{array}$ & Bergelombang & $\begin{array}{l}\text { Putih } \\
\text { kecokelatan }\end{array}$ & Runcing & Bergaris \\
\hline K8 & Cokelat Muda & 37.7 & 2 & $\begin{array}{l}\text { Segitiga } \\
\text { Memanjang }\end{array}$ & Bergelombang & $\begin{array}{l}\text { Putih } \\
\text { kecokelatan }\end{array}$ & Meruncing & Bergaris \\
\hline K9 & Cokelat Muda & 34.4 & 1.9 & $\begin{array}{l}\text { Segitiga } \\
\text { Memanjang }\end{array}$ & Bergelombang & $\begin{array}{l}\text { Putih } \\
\text { kecokelatan }\end{array}$ & Meruncing & Bergaris \\
\hline K10 & Cokelat Tua & 40.4 & 1.9 & $\begin{array}{l}\text { Segitiga } \\
\text { Memanjang }\end{array}$ & Bergelombang & Cokelat & Meruncing & Bergaris \\
\hline B1 & Cokelat Muda & 36.7 & 1.9 & $\begin{array}{l}\text { Segitiga } \\
\text { Memanjang }\end{array}$ & Bergelombang & $\begin{array}{l}\text { Putih } \\
\text { kecokelatan }\end{array}$ & Meruncing & Bergaris \\
\hline B2 & Cokelat Muda & 33.5 & 1.8 & $\begin{array}{l}\text { Segitiga } \\
\text { Memanjang }\end{array}$ & Bergelombang & $\begin{array}{l}\text { Putih } \\
\text { kecokelatan }\end{array}$ & Meruncing & Bergaris \\
\hline B3 & Cokelat Tua & 34.5 & 1.3 & $\begin{array}{l}\text { Segitiga } \\
\text { Memanjang }\end{array}$ & Bergelombang & $\begin{array}{l}\text { Putih } \\
\text { kecokelatan }\end{array}$ & Meruncing & Bergaris \\
\hline B4 & Cokelat Tua & 33.8 & 1.7 & $\begin{array}{l}\text { Segitiga } \\
\text { Memanjang }\end{array}$ & Bergelombang & $\begin{array}{l}\text { Putih } \\
\text { kecokelatan }\end{array}$ & Meruncing & Bergaris \\
\hline B5 & Cokelat Tua & 32.3 & 1.7 & $\begin{array}{l}\text { Segitiga } \\
\text { Memanjang }\end{array}$ & Bergelombang & $\begin{array}{l}\text { Putih } \\
\text { kecokelatan }\end{array}$ & Meruncing & Bergaris \\
\hline B6 & Cokelat Tua & 41.4 & 1.9 & $\begin{array}{l}\text { Segitiga } \\
\text { Memanjang }\end{array}$ & Bergelombang & $\begin{array}{l}\text { Putih } \\
\text { kecokelatan }\end{array}$ & Meruncing & Bergaris \\
\hline B7 & Cokelat Tua & 41.4 & 1.9 & $\begin{array}{l}\text { Segitiga } \\
\text { Memanjang }\end{array}$ & Bergelombang & Cokelat tua & Meruncing & Bergaris \\
\hline B8 & Cokelat Tua & 44.5 & 2.1 & $\begin{array}{l}\text { Segitiga } \\
\text { Memanjang }\end{array}$ & Bergelombang & Cokelat tua & Meruncing & Bergaris \\
\hline B9 & Cokelat Tua & 41.6 & 1.6 & $\begin{array}{l}\text { Segitiga } \\
\text { Memanjang }\end{array}$ & Bergelombang & $\begin{array}{l}\text { Putih } \\
\text { kecokelatan }\end{array}$ & Meruncing & Bergaris \\
\hline B10 & Cokelat Muda & 43.1 & 2.2 & $\begin{array}{l}\text { Segitiga } \\
\text { Memanjang }\end{array}$ & Bergelombang & Coklat & Meruncing & Bergaris \\
\hline
\end{tabular}

Keterangan: Biji dari semua sampel berkarpel (sayap) di tiga punggung biji. WB (Warna Buah), UB (Ukuran Buah), BB (Bentuk Buah), SP (Sifat Pinggang), K (Karpel), WDB (Warna Daging Buah), BUB (Bentuk Ujung Buah).

Total biji per buah kelor berbeda-beda. Biji per buah di Kecamatan Pemenang ratarata berjumlah 16 biji. Di Kecamatan Gangga memiliki rata-rata 15 biji. Di Kecamatan Kayangan dan Bayan memiliki 17 biji. Ukuran buah kelor di Lombok Utara tergolong pendek dibandingkan dengan ukuran buah kelor yang terdapat di Kenya yang pernah dilaporkan oleh Orwa et al. (2009), bahwa buah kelor kasar dan berukuran besar dan dapat mencapai panjang lebih dari $90 \mathrm{~cm}$. Berbeda dengan yang dilaporkan Roloff et al. (2009), bahwa buah kelor biasanya memiliki panjang $20-50 \mathrm{~cm}$, namun kadang-kadang dapat mencapai lebih dari 1 meter. Kelor di Pulau Jawa dilaporkan oleh Krisnadi (2015), memiliki panjang buah antara 20 $-60 \mathrm{~cm}$. Lebih lanjut Parrotta (1993), menjelaskan buah kelor di Puerto Rico memiliki panjang $20-45 \mathrm{~cm}$, kadang- kadang dapat mencapai $120 \mathrm{~cm}$, dan memiliki lebar $2-2,5 \mathrm{~cm}$. 
Buah kelor di Lombok Utara memiliki rata-rata panjang $37,6 \mathrm{~cm}$. Buah kelor di Lombok Utara memiliki kesamaan dengan panjang buah kelor di India, hal ini sesuai oleh Ramachandran et al. (1980) menyatakan bahwa buah kelor menggantung, berbentuk segitiga memanjang, biasanya mencapai panjang 20-45 cm, kadang-kadang mencapai $120 \mathrm{~cm}$, memiliki 3 karpel yang tebal dan seperti spons.

Tabel 5. Hasil Pengamatan Morfologi Biji Tanaman Kelor di Kabupaten Lombok Utara

\begin{tabular}{|c|c|c|c|c|c|c|c|}
\hline \multirow{3}{*}{$\begin{array}{c}\text { Tanaman } \\
\text { Sampel }\end{array}$} & \multicolumn{7}{|c|}{ Morfologi Biji } \\
\hline & \multirow[b]{2}{*}{ WB } & \multicolumn{2}{|c|}{ LSB } & \multirow[b]{2}{*}{ BB } & \multirow[b]{2}{*}{$\mathbf{K B}(\mathbf{c m})$} & \multirow{2}{*}{$\begin{array}{c}\text { Berat 100 } \\
\text { Biji (g) }\end{array}$} & \multirow{2}{*}{$\begin{array}{c}\text { Jumlah } \\
\text { Biji per } \\
\text { Buah }\end{array}$} \\
\hline & & p (cm) & l (cm) & & & & \\
\hline $\mathrm{P} 1$ & Cokelat Muda & 3 & 0.5 & Bulat & 1 & 17.91 & 13 \\
\hline $\mathrm{P} 2$ & Cokelat Tua & 2.7 & 0.8 & Bulat & 1.06 & 18.45 & 20 \\
\hline P3 & Cokelat Tua & 3.6 & 0.7 & Bulat & 1.09 & 18.77 & 16 \\
\hline P4 & Cokelat Muda & 3.4 & 0.6 & Bulat & 1.14 & 22.02 & 15 \\
\hline P5 & Cokelat Muda & 3.4 & 1 & Bulat & 0.99 & 17.81 & 22 \\
\hline P6 & Cokelat Muda & 3.6 & 0.6 & Bulat & 1.09 & 20.30 & 11 \\
\hline P7 & Cokelat Tua & 3.4 & 0.6 & Bulat & 1.10 & 20.05 & 15 \\
\hline P8 & Cokelat Muda & 3.2 & 0.7 & Bulat & 0.99 & 18.64 & 16 \\
\hline G1 & Cokelat Muda & 2.6 & 0.8 & Bulat & 1.07 & 25.10 & 13 \\
\hline $\mathrm{G} 2$ & Cokelat Tua & 2.2 & 0.6 & Bulat & 0.89 & 9.82 & 18 \\
\hline G3 & Cokelat Tua & 2.9 & 0.7 & Bulat & 1.07 & 22.61 & 17 \\
\hline G4 & Cokelat Muda & 4.1 & 1.1 & Bulat & 0.98 & 25.81 & 15 \\
\hline G5 & Cokelat Tua & 3.7 & 1.3 & Bulat & 1.21 & 26.35 & 11 \\
\hline G6 & Cokelat Tua & 2.7 & 0.7 & Bulat & 1.16 & 26.04 & 13 \\
\hline G7 & Cokelat Tua & 3.7 & 0.8 & Bulat & 1.10 & 25.19 & 19 \\
\hline G8 & Cokelat Tua & 3.5 & 0.7 & Bulat & 1.07 & 22.78 & 15 \\
\hline G9 & Cokelat Muda & 2.8 & 0.8 & Bulat & 1.10 & 26.06 & 15 \\
\hline G10 & Cokelat Tua & 2.9 & 0.7 & Bulat & 1.14 & 25.77 & 12 \\
\hline K1 & Cokelat Tua & 3.5 & 1 & Bulat & 1.06 & 18.80 & 18 \\
\hline $\mathrm{K} 2$ & Cokelat Tua & 2.2 & 0.6 & Bulat & 1.07 & 20.30 & 18 \\
\hline K3 & Cokelat Tua & 2.9 & 0.9 & Bulat & 0.96 & 16.86 & 17 \\
\hline K4 & Cokelat Tua & 3.1 & 0.8 & Bulat & 1.01 & 17.41 & 17 \\
\hline K5 & Cokelat Muda & 3.8 & 0.9 & Bulat & 1.07 & 18.53 & 17 \\
\hline K6 & Cokelat Tua & 3.1 & 1 & Bulat & 0.98 & 18.43 & 16 \\
\hline K7 & Cokelat Muda & 2.8 & 0.8 & Bulat & 1 & 19.00 & 17 \\
\hline K8 & Cokelat Muda & 3.1 & 1.1 & Bulat & 1.07 & 18.44 & 19 \\
\hline K9 & Cokelat Tua & 3.3 & 1 & Bulat & 0.88 & 17.25 & 16 \\
\hline K10 & Cokelat Muda & 3.3 & 0.8 & Bulat & 1 & 17.35 & 15 \\
\hline B1 & Cokelat Tua & 3.1 & 0.6 & Bulat & 0.99 & 17.85 & 22 \\
\hline B2 & Cokelat Tua & 2.8 & 0.9 & Bulat & 1.05 & 18.30 & 21 \\
\hline B3 & Cokelat Muda & 2.3 & 1.3 & Bulat & 0.97 & 18.15 & 16 \\
\hline B4 & Cokelat Muda & 3.3 & 1.6 & Bulat & 0.95 & 18.33 & 18 \\
\hline B5 & Cokelat Tua & 3.3 & 1.3 & Bulat & 1.10 & 22.66 & 15 \\
\hline B6 & Cokelat Tua & 2.5 & 1.5 & Bulat & 0.97 & 23.32 & 19 \\
\hline B7 & Cokelat Tua & 3.3 & 0.9 & Bulat & 1.09 & 19.13 & 12 \\
\hline B8 & Cokelat Tua & 3.8 & 1 & Bulat & 1.03 & 19.85 & 14 \\
\hline B9 & Cokelat Tua & 3 & 0.8 & Bulat & 1.11 & 18.28 & 14 \\
\hline B10 & Cokelat Muda & 3.8 & 0.9 & Bulat & 1.12 & 19.13 & 18 \\
\hline
\end{tabular}

Keterangan: P1 (Nama Kecamatan dan nomor urut sampel), WB (Warna Biji), LSB (Lebar Sayap Biji), BB (Bentuk Biji), KB (Ketebalan Biji).

Biji kelor berbentuk bulat dengan memiliki sayap yang berwarna putih di ketiga sisinya yang menjalar dari atas ke bawah. Bobot 100 butir biji kelor di Kecamatan Pemenang adalah 
19,24 g, di Kecamatan Gangga sebesar 23,55 g, di Kecamatan Kayangan sebesar 18,24 g dan di Kecamatan Bayan sebesar 19,05 g. Kecamatan Gangga yang memiliki Bobot 100 biji yang cukup besar yaitu dengan 23, 55 g. Hasil ini dipertegas oleh Parrotta (1993), bahwa biji berwarna cokelat tua, berbentuk bulat dengan ketebalan sekitar $1 \mathrm{~cm}$, memiliki tiga sayap. Lebih lanjut Parrotta (1993), melaporkan bahwa bobot 100 biji dari 2 sampel di Puerto Rico rata-rata seberat $0,325 \pm 0,005$ dan 0,310 $\pm 0,006 \mathrm{~g}$ per biji, atau sekitar 3.080 dan 3.230 biji per kg. Ketebalan biji kelor di Lombok Utara dapat dikatakan lebih tebal dibandingkan dengan kelor yang tumbuh di Puerto Rico.

Ukuran lebar sayap biji kelor aksesi Lombok Utara rata-rata 3,2 cm sedangkan bijinya memiliki ketebalan rata-rata $1,05 \mathrm{~cm}$. Ukuran ini serupa dengan biji kelor di India, yang dilaporkan oleh Ramachandran et al. (1980) bahwa biji berbentuk bulat, berdiameter sekitar 1 $\mathrm{cm}$, bersayap 3 dengan panjang 2-2,5 $\mathrm{cm}$ dan lebar $0,4-0,7 \mathrm{~cm}$.

\section{Hubungan Kekerabatan}

Analisis kekerabatan digunakan untuk menentukan jauh dekatnya hubungan kekerabatan antara takson tanaman (dalam hal ini aksesi) dengan menggunakan sifat morfologis dari suatu tanaman. Sifat morfologis dapat menggambarkan kekerabatan tingkat jenis. Jenis-jenis yang berkerabat dekat mempunyai banyak persamaan antara satu jenis dengan yang lainnya (Yuniarti, 2011).

Berdasarkan nilai jarak koefisien diperoleh kesimpulan bahwa semakin kecil nilai koefisien antara satu variabel dengan variabel lainnya, maka semakin dekat hubungan kekerabatan pada kedua variabel tersebut. Diketahui bahwa hubungan kekerabatan terdekat yaitu pada sampel B3 (Bayan 3) dan B4 (Bayan 4) dengan nilai koefisien sebesar 12,212 sedangkan hubungan kekerabatan terjauh yaitu pada sampel P1 (Pemenang 1) dan G2 (Gangga 2) dengan nilai koefisien sebesar 70,773.

Meskipun terdapat pada lokasi yang sama, ternyata tidak menjamin bahwa suatu tanaman memiliki tingkat hubungan kekerabatan yang dekat. Pada sampel P1 (Pemenang 1) dan P2 (Pemenang 2), meskipun terdapat di lokasi yang sama yaitu Kecamatan Pemenang, memiliki hubungan kekerabatan yang jauh dengan nilai koefisien sebesar 59,662.

Hubungan kekerabatan aksesi kelor di Kabupaten Lombok Utara diilustrasikan pada Gambar 1. Hasil analisis kluster dengan metode aglomeratif memperlihatkan bahwa aksesi kelor dari kecamatan yang sama belum tentu memiliki hubungan kekerabatan yang lebih dekat. Hubungan kekerabatan yang dekat dapat terjadi antar aksesi tanaman kelor yang berasal dari kecamatan yang berbeda. Tampak bahwa hubungan kekerabatan antar aksesi tanaman kelor memiliki tingkat kekerabatan yang dekat. Semakin besar jarak skala kombinasi kluster (0-25), maka semakin kecil tingkat kekerabatan yang terbentuk antar aksesi (Bayu et al, 2015). 
Tabel 6. Nilai Koefisien Tingkat Hubungan Kekerabatan Tanaman Kelor di Lombok Utara

\begin{tabular}{|c|c|c|c|}
\hline \multicolumn{4}{|c|}{ Pengelompokkan } \\
\hline \multirow{2}{*}{ Bagian } & \multicolumn{2}{|c|}{ Kombinasi Kelompok } & \multirow{2}{*}{ Koefisien } \\
\hline & Kelompok 1 & Kelompok 2 & \\
\hline 1 & B3 & B4 & 12.212 \\
\hline 2 & B1 & B2 & 14.629 \\
\hline 3 & K6 & B7 & 16.580 \\
\hline 4 & K5 & B10 & 19.442 \\
\hline 5 & P4 & G4 & 19.489 \\
\hline 6 & K3 & K4 & 20.036 \\
\hline 7 & B5 & B6 & 22.692 \\
\hline 8 & K6 & B8 & 23.889 \\
\hline 9 & $\mathrm{P} 1$ & K8 & 25.203 \\
\hline 10 & G6 & K3 & 25.573 \\
\hline 11 & G10 & $\mathrm{K} 2$ & 25.840 \\
\hline 12 & $\mathrm{~K} 5$ & B9 & 26.217 \\
\hline 13 & P7 & K10 & 26.330 \\
\hline 14 & G5 & G7 & 28.484 \\
\hline 15 & G9 & K9 & 28.544 \\
\hline 16 & G1 & K7 & 29.086 \\
\hline 17 & $\mathrm{P} 1$ & K5 & 30.843 \\
\hline 18 & G6 & G10 & 31.930 \\
\hline 19 & P3 & P7 & 32.015 \\
\hline 20 & $\mathrm{P} 2$ & P5 & 32.770 \\
\hline 21 & G1 & B3 & 33.156 \\
\hline 22 & G5 & K6 & 33.251 \\
\hline 23 & $\mathrm{P} 1$ & G6 & 34.204 \\
\hline 24 & G8 & K1 & 36.516 \\
\hline 25 & $\mathrm{P} 1$ & P3 & 38.494 \\
\hline 26 & G1 & B5 & 38.675 \\
\hline 27 & P6 & G3 & 40.191 \\
\hline 28 & G5 & G8 & 42.313 \\
\hline 29 & P4 & P6 & 43.753 \\
\hline 30 & $\mathrm{P} 1$ & G1 & 45.950 \\
\hline 31 & G5 & G9 & 47.243 \\
\hline 32 & $\mathrm{P} 1$ & G5 & 47.820 \\
\hline 33 & P1 & $\mathrm{P} 4$ & 53.743 \\
\hline 34 & $\mathrm{P} 1$ & P8 & 54.713 \\
\hline 35 & P2 & B1 & 55.888 \\
\hline 36 & P1 & $\mathrm{P} 2$ & 59.662 \\
\hline 37 & $\mathrm{P} 1$ & $\mathrm{G} 2$ & 70.773 \\
\hline
\end{tabular}




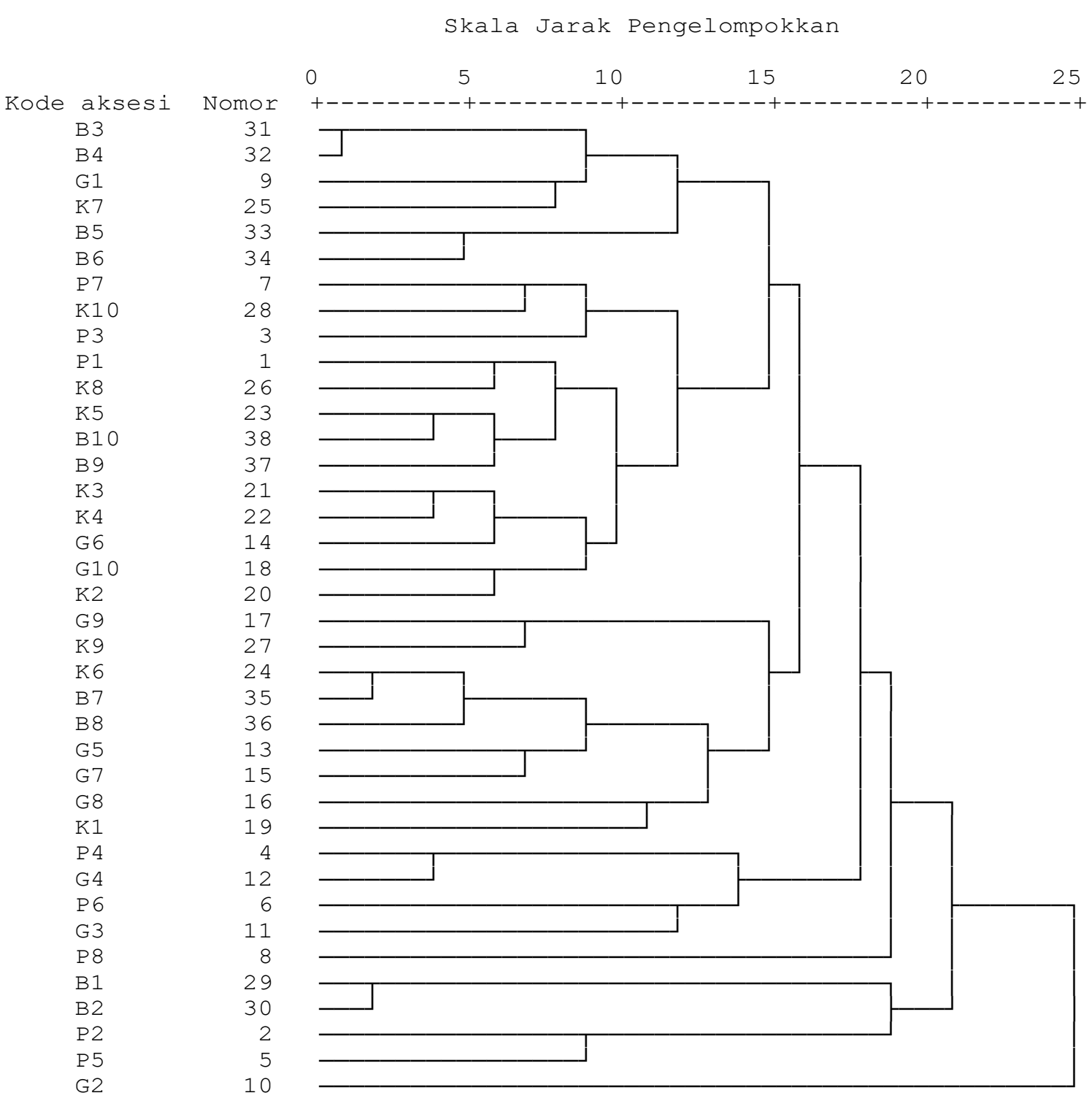

Gambar 1. Dendogram tanaman kelor aksesi-aksesi Kabupaten Lombok Utara

Aksesi tanaman kelor Lombok Utara terbagi ke dalam 8 kelompok. Kelompok 1 beranggotakan B3, B4, G1, K7, B5, dan B6. Kelompok 2 beranggotakan P7, K10, P3, P1, K8, K5, B10, B9, K3, K4, G6, G10, dan K2. Kelompok 3 beranggotakan G9, K9, K6, B7, B8, G5, G7, G8, dan K1. Kelompok 4 beranggotakan P4, G4, P6, dan G3. Kelompok 5 beranggotakan hanya P8. Kelompok 6 beranggotakan B1 dan B2. Kelompok 7 beranggotakan P2 dan P5. Kelompok 8 beranggotakan hanya G2. Pengelompokkan ini didasarkan atas kesamaan karakter morfologi dan pemisahan terjadi didasarkan atas perbedaan karakter morfologi yang terdapat di antara aksesi tersebut.

Hal menarik dapat dilihat pada sampel Gangga 2 (G2) bahwa dari hasil analisis dendogram menunjukkan terjadi hubungan kekerabatan yang cukup jauh dengan aksesi yang lainnya, hal ini ditunjukkan pada skala 25 barulah terjadi kemiripan dengan aksesi yang 
lainnya. Terjadinya perbedaan yang jauh ini diduga diakibatkan oleh faktor lingkungan tempat tumbuh aksesi tanaman dan ketinggian tempat asal aksesi tersebut.

Hubungan kekerabatan 38 aksesi tanaman kelor di Lombok Utara dari beberapa karakter morfologis yang diamati dan diukur menunjukkan bahwa pengelompokkan berdasar atas banyaknya tingkat kesamaan karakter morfologi yang dimiliki. Singh (1999) dalam Sumarjan (2001) menyatakan, bahwa organisme dalam jenis yang sama memiliki 85\% kemiripan, tetapi nilai kemiripan ditentukan oleh data yang cukup dan ketepatan pada saat pengamatan.

Tingkat perbedaan kemiripan dan ketidakmiripan ini disebabkan adanya perbedaan karakter morfologis antar aksesi di Kabupaten Lombok Utara baik itu perbedaan secara kualitatif maupun perbedaan secara kuantitatif. Karakter-karakter kualitatif yang menyebabkan suatu perbedaan adalah seperti tingkat kerimbunan dan arah tumbuh, bentuk dan warna daun, bunga, buah dan biji. Sementara karakter kuantitatif dapat berupa tinggi tanaman, ukuran panjang dan lebar daun, bunga, buah dan biji. Perbedaaan karakter morfologi antar aksesi kelor juga dapat dipengaruhi oleh faktor genetik dan lingkungan tempat tumbuh (Yuniarti, 2011).

Meskipun ditanam pada suatu daerah yang sama tetapi jika lingkungan mikro ataupun asal bahan tanaman awal tempat tumbuhnya berbeda maka akan dapat mempengaruhi pertumbuhan dan perkembangan tanaman yang di ekspresikan melalui penampilan morfologinya. Hal ini sesuai dengan Irawan dan Purbayanti (2008), bahwa meskipun suatu kultivar berasal dari daerah yang sama namun bila lingkungan tempat tumbuhnya berbeda akan mempengaruhi diversitas genetik dan juga genotipe yang berasal dari daerah yang sama tidak selalu berada dalam kelompok yang sama. Semakin banyak persamaan ciri, maka semakin dekat hubungan kekerabatannya. Sebaliknya semakin banyak perbedaan ciri, maka semakin jauh tingkat hubungan kekerabatannya.

\section{KESIMPULAN}

Populasi kelor aksesi Lombok Utara terbagi menjadi 8 kelompok dan pada garis fenon distance 25 terjadi penggabungan antara aksesi Gangga-2 dengan kelompok aksesi di Lombok Utara. Hubungan kekerabatan genetik tanaman kelor aksesi Kabupaten Lombok Utara yang terdekat yaitu aksesi Bayan-3 dan aksesi Bayan-4 dengan nilai koefisien sebesar 12,212 sedangkan kekerabatan genetik terjauh antara aksesi Pemenang-1 dan aksesi Gangga-2 dengan nilai koefisien sebesar 70,773. Jadi dapat dikatakan bahwa hubungan kekerabatan tanaman kelor aksesi Lombok Utara masih memiliki tingkat hubungan kekerabatan yang dekat.

Untuk program pengembangan tanaman kelor aksesi Lombok Utara dapat dipilah menjadi dua sasaran pengembangan, yaitu aksesi yang memiliki potensi menghasilkan biomassa daun yang baik adalah aksesi Pemenang-1, Pemenang-7, Gangga-5, Gangga-8, Kayangan-2, Kayangan-5, Bayan-3, Bayan-4, Bayan-5, dan Bayan-6. Sedangkan yang memiliki potensi menghasilkan buah yang baik, adalah aksesi Pemenang-2, Pemenang-5, Gangga-3, Gangga-7, Gangga-9, Kayangan-2, Bayan-5, Bayan-6, Bayan-7, dan Bayan-10. 


\section{Ucapan Terima Kasih}

Disampaikan kepada Kemenristekdikti Republik Indonesia atas penyediaan dana penelitian melalui Skim Penelitian Produk Terapan Unggulan Perguruan Tinggi (PTUPT) dengan Nomor Kontrak 074/SP2H/LT/DRPM/IV/2017.

\section{DAFTAR PUSTAKA}

Alessandro, L., Alberto S., Alberto B. , Alberto S., Junior A., Simona B. 2015. Cultivation, Genetic, Ethnopharmacology, Phytochemistry and Pharmacology of Moringa oleifera Leaves: An Overview. Int. J. Mol. Sci. 16, 12791-12835.

Aminah S., Ramdhan T., Yanis M. 2015. Kandungan Nutrisi dan Sifat Fungsional Tanaman Kelor (Moringa oleifera). Buletin Pertanian Perkotaan. 5(2).

Badan Pusat Statistik. 2016. Kabupaten Lombok Utara Dalam Angka 2016. Badan Pusat Statistik. Lombok Utara.

Bappeda Kaur. 2014. Morfologi Tanaman Kelor. http://bappeda.kaurkab.go.id/? page id=26. [10 Januari 2017].

Bayu E.S., Aryanti I., Kardhinata E.H. 2015. Identifikasi Karakteristik Morfologis dan Hubungan Kekerabatan pada Tanaman Jahe (Zingiber officinale Rosc.) di Desa Dolok Saribu Kabupaten Simalungun. Jurnal Agroekoteknologi. 3(3): 963-975.

Devi S. 2012. Kelor. http://sridevi1112.wordpress.com/biologi/kelor.html. [26 Januari 2017].

Fahey, J.W. 2005. Moringa oleifera: A review of the medical evidence for its nutritional, therapeutic, and prophylactic properties. Part 1. Trees for Life Journal. 1: 5

Fuglie, JW. 2001. The miracle tree: Moringa oleifera, natural nutrition for the tropics. Training Manual. Dakar, Senegal; Church World Service. P. 172.

Irawan B., Purbayanti K. 2008. Karakterisasi dan Kekerabatan Kultivar Padi Lokal di Desa Rancakalong, Kecamatan Rancakalong, Kabupaten Sumedang. Seminar Nasional PTTI 21-23 Oktober 2008.

Krisnadi A.D. 2015. Kelor Super Nutrisi. Kelorina.com. Blora.

Luthfiyah F. 2012. Potensi Gizi Daun Kelor (Moringa oleifera) Nusa Tenggara Barat. Media Bina Ilmiah 6: 42-43.

Mayr E., Ashlock P.D. 1999. Principles of Systematic Zoology. Second Edition. McGraw Hill International Edition. New York.

Morton J.F. 1991. The Horseradish Tree Moringa pterygosperma (Moringaceae) - A boon to arid lands. Econ. Bot. 45: 318-333.

Orwa C., Mutua A., Kindt R., Jamnadass R., Anthony S. 2009. Moringa oleifera Lam. Moringaceae. Agroforestree Database: a tree reference and selection guide version 4.0:1.

Parrotta J.A. 1993. Moringa oleifera Lam. Reseda, Horseradish Tree Moringaceae Horseradish-tree family. SO-ITFSM-61.

Price M.L. 1985. The Moringa Tree. Echo Technical Note.

Ramachandran C., Peter K.V., Gopalakrishnan P.K. 1980. Drumstick (Moringa oleifera): A Multipurpose Indian Vegetable. Economic Botany, 34 (3): 276-283. 
Roloff A., Weisgerber H., Lang U., Stimm B. 2009. Moringa oleifera Lam. ISBN: 978-3-52732141-4.

Samingan, T. 1982. Dendrologi. PT.Gramedia. Jakarta.

Sumarjan. 2001. Klasifikasi Padi Lokal (Oryza sativa L.) Di Lombok Berdasarkan Sifat dan Ciri Morfologi-Anatomi. [Tesis Magister, unpublished]. Sekolah Pasca Sarjana Universitas Gadjah Mada. Yogyakarta. Indonesia.

Tsaknis, J., Lalas, S., Gergis, V., Spiliotis, V., 1999. A total characterisation of Moringa oleifera Malawi seed oil. Riv. Ital. Sost. Gras. 75(1): 21-27.

Yuniarti. 2011. Inventarisasi dan Karakterisasi Morfologis Tanaman Durian (Durio zibethinus Murr.) di Kabupaten Tanah Datar. Jurnal Plasma Nutfah. 3(2): 23-31. 